\title{
A Study on the Direction of Christian Home Education in the Fourth Industrial Revolution
}

\author{
Eun-Ha Joo ${ }^{1}$, Dong-Il Kim ${ }^{2}$, Mi-Na Lee ${ }^{3}$ \\ ${ }^{1}$ Student, Graduate School of Human Service Education, Kwangshin University, \\ jeh1483@hanmail.net \\ ${ }^{2}$ Outpatient Professor, Department of Human Service Education, Kwangshin University, Gwangju, \\ ks04014@hanmail.net \\ ${ }^{3}$ Professor, Kwangshin University Welfare Counseling Convergence Department, Gwangju, \\ lmn4780@naver.com
}

Corresponding author: Mi-Na Lee

\begin{abstract}
The 21st century brought about a rapidly changing knowledge and information society which disrupts the identity of the Christian faith and creates confusion among the people. Efforts, including Christian education, are needed to avoid this disruption and to find a fundamental solution to adapt to the new paradigm of this era. The transformation of the new paradigm of 21 st-century education focuses on theory and practice, which were already recorded in the Bible. Philippians 4 says, "Let ye learn, receive, hear, and do what I have seen, and the God of peace will be with you." As mentioned in the Bible, Christianity is the core of Christian education to learn, hear, receive, and do the Word of God. Therefore, the recovery of the community of Christian families will be restored through the process of knowing God to do the Christian way of living. Therefore, to find out the direction of Christian home education in the 21st century, we would like to examine the relationship between the church and home, the role of home, and the direction of Christian education.
\end{abstract}

Keywords: Fourth Industrial Revolution, Christian Education, Family, Church, Community Recovery

\section{Introduction}

Education is human teaching for the next generation and has been the history and culture of people, and accepting this knowledge of culture and the process of becoming a human being. Human beings need constant education through the process of living together. The 21 st century will inevitably have difficulties in practicing learning and doing[1].

The story of God's words to the next generation is being cut off. The rapidly changing modernization of the 21 st century affected their interests in the stories of ancestors that have been kept so far. The generation listening every day to the Word of God reduces. What will happen to a generation unaware of the Bible stories? This will lead us to a dark history, with answers stated from the Book of the Judges[2].

"And the children of Dan set up the graven image: and Jonathan, the son of Gershom, the son of Manasseh, he and his sons were priests to the tribe of Dan until the day of the captivity of the land."(Judges 18:30)

Therefore, for sustained growth, all educational activities in churches and homes must be done constantly. In addition, one should have a passion and direction for Christian education, namely a

Received: July 20, 2020; 1st Review Result: September 10, 2020; 2nd Review Result: October 27, 2020 Accepted: November 30, 2020 


\section{Christian worldview.}

The relationship between Judaism and Christianity has become blurred by the institutional division long ago and the continued separation of the two. In the Bible, Jesus was raised in a Jewish family and attended Jewish schools, based on the most representative lessons of Hebrew prophets. Although the lessons, standards, and ideals of Jesus were born from life for approximately two thousand years, the spiritual experience based on ancient Hebrews has influenced and guided Christianity, which has continued to develop[3]. The 21st century is a knowledge and information society, which is a new society caused by the rapid development of ICT. The rapid development of technology confuses the foundations of society specifically the identity of every person. This confuses not only individuals but also the state and society, and to overcome it, we are making every effort to explore the new order.

In this sense, it is also a time when a paradigm shift in all sectors of society is required and accompanied. Christian education cannot be an exception as it cannot be free from this fundamental demand for social change. Rather, the fundamental solution to building a knowledge and information society can only be completed by changes in the educational paradigm which does not require very new things. The education of the ancient Greeks means a comprehensive process of intentional and indirect formation that prepared them to participate in the praxis to be accepted as a member of the urban state. This refers to changes due to mutually complementary and organic relationships with knowledge and practice[4]. Christian education should be a practical education of God's knowledge, practice, and words. Homes should consist of an integrated education where theory and practice are not separated by an education that communicates with the world. Therefore, to seek the direction of Christian home education in the 21 st century, this study would examine the relationship between the church and the family, what the role of the family is as a small community of the church, and the direction of Christian education towards the recovery of a family community.

\section{Christian Family and Parental Education}

Parental education is a universal term that is widely used, but it is defined in many ways depending on the approach or object of parent education. It ranges from the perspective of special education by educating general experts, teachers, and parents about the knowledge needed for child-rearing to the position that allows parents to participate in active and active child-rearing and education courses by having the same level of knowledge and skills as experts. Parental education can be defined as parent education, which not only allows parents themselves to provide efficient education for their child's upbringing and development but also facilitates interaction between home and infant institutions, helping them achieve their child's development positively and more efficiently.

Looking at parent education from the perspective of the times, the theory of parent education before the 19th century tended to emphasize moral discipline, but as it entered the second half, scholars came to emphasize objective and scientific methods.

In addition, the parent's child care center was perceived as being personal from the tendency not to treat children personally, and the parenting method also developed from the adult-centered to childcentered or the vertical relationship of parent relationships into a horizontal relationship

The families of the Hebrew people's communities made it a place to train their faith in God, who was with them and helped them in the history of the people through their families. In other words, families as worship devices took precedence over education or friendship. The intercourse with God was done through worship.

God is the ruler, and the whole realm of human life is under God's absolute sovereignty, and the assumptions underlying that realm of life should be the scene where God's absolute sovereignty is revealed and represented. And the clearest and clearest evidence that man can represent God's absolute sovereignty is "Christianity." As an instrument of worship, Christian families have the meaning of 
"church." Proverbs 22:6"Start children off on the way they should go, and even when they are old they will not turn from it." emphasized parent's education is needed in their childhood

Parental education in the New Testament can be found in infant baptism. Through infant baptism, Christian parents pledge their educational responsibility for nurturing. Children's baptism is given by their parent's faith, and through answering questions and answers, they are pledged to raise their children well with the word of the Lord. If you look at the contents, you will see the following (the question of the baptism of infants in the Constitution).

First, do you acknowledge that your child needs to be bathed in the blood of Jesus Christ and receive the Holy Spirit's renewed grace?

Second, do you insist on the covenant of God on your children's behalf as you do for yourself and desire and seek their salvation in faith in the Lord Jesus Christ?

Third, do you now have no hesitation in leaving your child to God and his covenant, humbly relying on God's grace to serve as a pious example before your children, pray with them and for their children, teach him the teachings of our holy religion, through all the means God has ordained, and make every effort to teach him?

Parents show the need for Christian education and the need for parental education, emphasizing that parents are responsible for it by pledging educational responsibility for their children in front of the congregation and God through infant baptism.

Parents who are Christians should guide their children to live the right life as Christians by teaching their children the words of God. Because the primary responsibility of the child's religious upbringing lies with its parents.

Like this, the Bible talks about parent education in detail. Parents need to educate and train their children to help their children grow through God's method, God's will, and the duties, responsibilities, and authority given to their parents with a servant mission. As above, children born to Christian families need parental education in the home to have a healthy growth and development with identity as children of God, and parents who are entrusted with precious children entrusted to God must receive parental education to take good care of their roles.

Parents' child-nurturing behavior is an authoritarian method of control that gives their children a lot of affection and interest, but forces them to follow their parents' standards and demands, and should serve as a helper to help them grow up in the knowledge of God through the formation of a whole personality. Parental education begins on the premise that parents impact their children and that parents are educated and effective for their children. The ultimate purpose of Christian parent education is to help parents learn the knowledge, ability, and attitudes necessary for parents to understand, help and guide their children. This is because parents make changes to their children by improving their selfrespect by acquiring appropriate knowledge and skills to effectively perform their role as guardians and educators. The ultimate goal of parent education is to help parents understand their children's developmental characteristics and acquire the necessary knowledge, skills, attitudes, etc. to raise their children.

In the general sense, if the purpose of parent education is focused on the growth and happiness of the child, in the biblical sense, the purpose of parent education is focused on God's will.

Parents who become the mirror of their children will live a life of influence in society by cherishing others if they show their children from an early age as a person who can look at the wide world and see the environment.

In the process of completing one's self, there must be education for complete self-completion, and Christian education desperately needs the education method that God wants. 


\section{Relation of Church-Family}

General education and education in churches have the following points[2]: first, a person is the focus of all the educational activities; second, teaching is a deliberate act of wanting change; third, the essential elements of education, such as teachers and students, content and methods, and environment, work together dynamically, and; fourth, teaching and learning are whole-hearted acts. However, Christian education is also different from general education. It teaches, first, that the living God is the basic premise of education. Second, a person is perceived as a creature named in the image of God. Third, the general revelation, which is God's revelation, and the Bible, which is a special revelation, are the fundamental contents of education. Fourth, education is focused on the restraint of Christ. Fifth, it is presupposed that the power of the Holy Spirit is the basic power. Calvin describes the church as a community of the chosen. This church community is referred to as the head of the Savior across all generations, tightly linked to each other by the Father, the Son, and the Holy Spirit. Calvin's church theory, therefore, is a church theory that depends on the choice of God thoroughly. He also compared the church justice to his mother. This is an emphasis on the absolute necessity of the Church. In God's eyes, believers are like children and need God's warm care, protection, and guidance. And the church is visible, not an inviolable one. As such, the church is the only institution of salvation given by God, helping the weakness of humans, and enabling them to be raised with words. That is why he left the church and said he was denying God and Christ[5]. The Jews had the origins of the ancient Jewish kingdom that collapsed in $586 \mathrm{BC}$, and the fallen Jews scattered across the region from Egypt to Mesopotamia, leading to the life of a refugee community. In other words, they formed a diaspora. Diaspora etymologically originates from the Greek preposition dia (over in English, over ' $\sim$ ' in Korean) and the verb Spero (over 'to see' in English and 'seed' in Korean). It is commonly used as a concept of national separation, referring to not only the process of dispersing national support but also the dispersed homogeneous communities and places of residence. Originally, the concept of diaspora was an active and positive concept that occurred between 600 B.C. and 800 B.C. in the course of the ancient Hela Empire's migration of its people to build colonies of lands that invaded and conquered the Mediterranean coast. Later, diaspora referred to a passive and negative concept of Jewish wandering[6]. The first temple is the destruction of Jerusalem in 586 B.C. and the destruction of the second temple in 70 A.D. brought together in the form of traditional gates to maintain and preserve their national identity. Much of the book of the Jewish law, including the Torah and the Prophecy, as well as the collection of writings, such as Mishna and Talmud, have been compiled. As it was recorded in the Bible, many contents were connected to the academic tradition of Judaism. These literary works include the first, Talmud, Siddur (prayer book), Hagada (the Passover prayer book), and Johar (the Jewish mysticism doctrine) (Carl, 2008). Jews have the concept of a holy temple of a family. In the beginning, God created man and woman and families (Genesis 2:18-24). The first family of Adam and Eve, the first man and woman, was the Divine Origin. Families are formed by God's creative order and are the scene of community life where a man is born and raised and learns everything necessary for life. In particular, the term Christian family goes beyond the meaning of natural, psychological, or social terms and aims for the purpose and will of God, who created the family and gave it meaning[7]. Before we live, Christian families are God's homes and children are God's children, not ours. Therefore, Christian families should take the lead to achieve the kingdom of God, and they can be blessed with the greatest happiness and glory of God when they raise their precious children with faith so that they can fulfill their God's kingdom of arrest[8]. God sent his son Jesus to this world through a mother and brought him up in the family. As such, God emphasized the spiritual importance of marriage and family. Jesus called God the Father and called the people God's children, so he presented the house of God as a model for a new family. On the ground, families become educational tools to explain their relationship with God to those who have become God's children in Jesus[7]. John Wesley (1703-1793), a British religious reformer and founder of the 
Methodist Church, was born to his father Samuel Wesley, a bishop of the Anglican Church, and his pious mother Susanna Wesley. John Wesley's parents provided Puritan home education to systematize their children's spiritual lives. In other words, they were educated with the highest purpose of saving their children forever. She did her best to raise her children holy at home. Later, he started a Methodist movement after his mother's death. Thus, Wesley's religious thought frame was already set at home. In other words, he became the basis of a small church movement in which his theology had a practical character in the background of a Christian family[9].

\section{Role of Family}

In Jewish history, families are recognized as the most basic educational institution. Both parents have their children's education, but the primary responsibility lies with the father, who is the head of the family. The mother also plays a role as a teacher and herself. In addition, parents are responsible for educating their children, and their passion for education is very high for their children because of God's orders[3].

And thou shalt teach them diligently unto thy children, and shalt talk of them when thou sittest in thine house, and when thou walkest by the way, and when thou liest down, and when thou risest up.

8 And thou shalt bind them for a sign upon thine hand, and they shall be as frontlets between thine eyes. 9 And thou shalt write them upon the posts of thy house, and on thy gates. (Deuteronomy 6:7-9)

The reason is that there is a strong expectation of children in the Bible.

Lo, children are a heritage of the LORD: and the fruit of the womb is his reward.

4 As arrows are in the hand of a mighty man; so are children of the youth.

5 Happy is the man that hath his quiver full of them: they shall not be ashamed, but they shall speak with the enemies in the gate."(Psalm 127: 3-5)

He said that religious education, in which God's will is delivered and brought to life as a tool for realizing God's will on this land, is a living field[10]. Jews made their families a place to train their faith in God, who helped them in the history of the people. In other words, the family is the institution of worship, the education, and the place of friendship, which was the highest priority through worship with God. He also stressed the need for cooperation and efforts of parents, teachers, media, and leaders in various sectors of society, as well as teachers in schools, parents in families, and leaders in all sectors of society[11]. Likewise, Christian home education requires cooperation and effort from both parents and teachers and church leaders or pastors.

\section{Christian Education for Community Recovery}

Comenius outlines three principles of Christian education for community recovery. It is about teaching everyone (Omnes), the whole (Omnia), and the whole thoroughly (Omnino). The meaning of teaching everyone is to enable people of all ages, people with innate thinking skills, to be fully aware of the world of things.

First, teaching (Omnes) to everyone. The 'God Shape Theory' we understand means that community recovery is entrusted by God. Therefore, things should be taught to fundamentally understand and use correctly. True wisdom and true happiness are based on the insight into the right perception of things and the basis of things and their correct use. Therefore, everyone must know things correctly and learn to grasp them from their sources. When that happens, you learn to use it easily and naturally. This will only be achieved if the lost paradise is restored and the whole world becomes a paradise of joy for God, men, and nature.

Second, teaching the whole (Omnia). Comenius believes that humans are born with the power to acquire knowledge of all things. Therefore, humans can and must learn everything about the whole, that 
is, God-nature-human. Man, by nature, possesses elements of stimulus and motivation in his heart. In fact, in the abyss of infinity, man is a persistent force that constantly rises and struggles toward God. With that purpose, a man enters the world and learns to seek God and recognize the Creator by his creation, until the time comes when God has revealed himself by looking face to face without being hidden from man. Therefore, we should all learn the whole (unification).

Third, teaching thoroughly (Omnino). Comenius refers to improving humanity, which not only leads everyone to perfection throughout the whole but also makes everyone fundamentally complete. We must require that everyone be thoroughly improved, not superficial. It should be improved in line with the truth of the world of things, not in pursuit of the delusion or shadow of the world of things because it is only an illusion that appears dimly without things (light of things). Therefore, we should be guided not by a superficial knowledge of the world of things, but by insight into the inner bases of man. A true teacher needs, first, insight into the whole. Through this, everyone can be taught as a whole, and secondly, simplicity is needed to reach a definite goal in a certain way, and third, sacredness is needed for everyone to accept and enjoy, like a single play.

Man is a creature that reflects God on the creation of the world, a creature that represents the world, or Mikokosmos(a small universe). But by using God's freedom to deal with things at random, the world became a maze. Therefore, Comenius said that we must strive for human completion of education to restore the world that has become a labyrinth. Education presupposes that self-sacrifice is through the cross of the maternal God and that human beings have the ability and opportunity to regain their original "image of God" and participate in the creation of God's new world. Therefore, the education of Comenius is 'faith education'.

\section{Goals of Christian Home Education}

The top goal of home education is to live properly. The goal of the Jewish family school is to live properly. To live properly is to live according to God, first of all. Second, it is a life that lives. These two are the goals of home education and living properly

Genesis 18:19 "For I have chosen him so that he will direct his children and his household after him to keep the way of the Lord by doing what is right and just so that the Lord will bring about for Abraham what he has promised him." The reason why God chose us through Jesus Christ is to let us live according to God's will and to give our children the same blessing.

God called Abraham and promised him these blessings. Genesis 12:1-3 "He promised the blessing of a great nation, the blessing of a great nation, the blessing of a great name, and the blessing of a great blessing. Abraham believed in the promise of the blessing of a great nation and God who made the impossible possible.

He chose Abraham to give such blessings to Abraham's descendants, so teach him that a Christian family school education can be blessed."

He promised the blessing of a great nation, the blessing of a great name, and the blessing of a great blessing. Abraham believed in the promise of the blessing of a great nation and God who made the impossible possible.

He chose Abraham to give such blessings to Abraham's descendants, so teach him that a Christian family school education can be blessed.

God promised Abraham that he would give him the blessing of making his name great. The goal of home education is to educate children to become people who are needed, not famous.

God promised Abraham the blessing of blessing. The goal of home education is to make children the source of good blessings. Like this, God chose Abraham to be the source of blessing and to teach his children and make them so, and he chose Christian families of this age.

"I will make the great nation through you and I will bless you and make your name great, and you 
will be the source of blessing." This is the blessing that is the source of the blessing. The Bible clearly states that the goal of Christian home education is to bring good blessings from the man like water from the fountain.

Talmud says the family is the heart of the people. The heart is the most important part, and when the heart stops, it is death at that moment. Just as a paralysis of the heart causes paralysis in everything, paralysis of the family paralyzes the nation. Jews lost their country in 1900 and ran away with their families. Because the family was always healthy, Hitler could kill the Jews but not destroy the Jewish family.

The meaning of being God's family means that God blesses you only when you are God's family. There must be three conditions for the meaning of being God's family. First, the whole family must believe in God.

Second, the whole family must read and study the Bible every day, but not a single day and no one should be left out.

Third, the whole family should pray every day.

Then God has an unbearable heart to bless the family, and God's eyes are turned back to it, and God's grace and blessing come.

\subsection{The Father's Role of a Christian Family}

As the head of a family and as a husband and father, you must faithfully fulfill your role as a guide, supplier, and guardian friend, always guide your family to heavenly homes, take care of your family and provide them with needs.

As the head of the household, the family will be able to form a model of a small paradise when they love their wives, encourage their children, pay deep attention, and lead their families to green chili paste.

A father is a way of blessing his children. If a father is a man of blessings, it would be natural for a child to lead to blessings.

A child who grows up with his father's blessing will grow well mentally. A father must open his mouth and bless his children. With the words and lessons of the Lord, you must give your children no encouragement and bless them in the language of life and love. We should give our children the right self-image, continue to have a constant interest in them, develop their talents and abilities, teach them with patience and kindness, show endless patience, and communicate with them in fun and creative ways through creative play and educational methods. As well as, a father should be the right authority for his children but the authority of love. This authority should lead their obedience by example through a life of sacrifice to their children through the harmony of mercy and dignity, and truth and compassion before simply ordering and blaming.

\subsection{The Role of Mothers to Christian Families}

The Jewish people have been educated by their mothers. My mother is a teacher at home. So Paul said to Timothy,(Deuteronomy 1:3-5). "3 In the fortieth year, on the first day of the eleventh month, Moses proclaimed to the Israelites all that the Lord had commanded him concerning them. 4 This was after he had defeated Sihon king of the Amorites, who reigned in Heshbon, and at Edrei had defeated Og king of Bashan, who reigned in Ashtaroth.

5 East of the Jordan in the territory of Moab, Moses began to expound this law, saying: This faith was first in your maternal aunt Lois and your mother's Uni-ge, and I am sure it is in you." Timothy was educated by her mother. My mother received faith from my grandmother. The tradition of the family flows from the mother or the woman.

Mother's breasts are children's classrooms and mother's love and prayer are textbooks that teach 
children. God allowed infinite possibilities in children's hearts. The mother's share of how much she can make use of her children with infinite possibilities in their lives is too large and the mother's role is too important." Impress them on your children. Talk about them when you sit at home and when you walk along the road, when you lie down and when you get up. "(Deuteronomy 6:7)

Lincoln's mother, Nancy, was Lincoln's father, Thomas, a carpenter and poor but diligent and healthy pioneer of Kentucky. Lincoln's mother, Nancy, was then a wise woman, the niece of a prestigious aristocratic family.

When Lincoln's father gave his son the name Abraham, but he was not interested in education at all and did not even think about sending him to school, Nancy was so obsessed with the education that she convinced her husband to go there with Lincoln and his sister Sarah when she heard that there was a place only for reading and writing about 14 kilometers away. However, Lincoln's mother left this will to his two young children when he died of endemic diseases when he was nine years old. "Be a person who enjoys reading the Bible rather than being rich or great." She read the Bible her life with her two young children sitting on her lap after dinner all the time. It was no coincidence that much of Lincoln's inaugural address when he later became president was woven into the Bible's words. Looking at the role of mothers, mothers have played a valuable role for their children as social objects they feel are the most important beings.

In the process of pregnancy, childbirth, and parenting, they have a relatively deeper bond with their children than their fathers.

The mother, who is the first person to be attached to her child, feels maternal love from the moment she is pregnant and plays the role of guardian and caregiver until the children become independent.

\section{Education in the Fourth Industrial Revolution}

From the 1990s, having the Internet commercialized and disseminated within 20 years and the mobile phones being widely available within 14 years to the whole world shows that technological advances and their ripple effects are surprisingly fast. The cycles of new technology and consequent innovation are decreasing, and the impact is increasing. This is easy to understand when we think about smartphones disappearing from our daily lives[12].

As such, mankind has passed through the era of the first and second industrial revolutions and is living amid the trend of the third industrial revolution and the fourth industrial revolution that is proceeding at a rapid pace. The first industrial revolution also called the steam engine-based mechanical revolution, is when the domestic industrial production system changed to a factory-produced system in 1784 . The second industrial revolution included production systems run with electric power in the late 19th century, which featured mass production systems in the industry. The third industrial revolution is a digital revolution including information and communication technology (ICT), big data, artificial intelligence, and digital nanotechnology. The latest, the fourth industrial revolution, has a distinctive feature of technological convergence, highlighted by artificial intelligence as its key factor.

The manipulative definition of the concept of the Fourth Industrial Revolution means the convergence of intelligent information technology and various industry-related technologies that make up the intelligence information society, thus, revolutionizing the industrial and social structure. It refers to the innovative changes in jobs, housing styles, and lifestyle culture in line with the revolutionary changes in industrial and social structure, and brings about great changes in the field of education due to these revolutions. It is an era of uncertainty as revolutionary changes continue beyond expectation.

Therefore, the human resources required in the era of the Fourth Industrial Revolution will be different from what they are now, and therefore changes in knowledge and skills to be learned are expected. The human beings of function will disappear, and the human beings of spirit (spirituality) and consumption will exist[13]. 
The source of knowledge in Christian education is the Bible. The Bible itself is knowledge. Therefore, truth is discovered through the Bible, which is the source of knowledge and truth. The Bible focuses to educate the learner with lessons, reproach, uprightness, and righteousness, so that he may be a man of God and have the ability to do all good (Timothy 3:17).

The basis of all values is God, the nature of God, the purpose of God, and the word of God[14]. In other words, the theological and philosophical basis of God's creations in the Bible reflects the universal value of the purpose intended in individual domains.

Christian education allows learners to know how the truth of the Bible is connected to their lives. At this time, learners should actively participate in all courses of education with the desire to learn, prepare to learn, and expect to learn. As such, everyone's preparation for learning should be done well[15]. A research report on future education that analyzed the latest data put together the following educational talent awards. In other words, creative and fusion talented human beings, cultured humans, creative humans, human beings who live together, people who contribute to mankind by combining humanity and creativity, people who are capable of solving practical problems based on creative entrepreneurship and creativity, and people with the sensitivity and personality capabilities are needed for collaboration[16]. In the coming future society or the era of the Fourth Industrial Revolution, we will experience a significantly different innovative change in many parts of occupations

Given that the ability to live in the era of the fourth industrial revolution must be learned through education, it must respond to the demands of social change. It is necessary to gather opinions from various areas on what talent and core competencies are required for the next generation of learners who will have to live in the society of the coming future and present alternatives. In addition, Christian education also needs to think about the talent and core capabilities they need to provide to the next generation, who are supposed to live in the whirlwind of innovative changes in the era of the fourth industrial revolution so that they can live as the people of God's kingdom.

The Korea Educational Development Institute's report[17] proposed creative, cooperative, and empathetic talent awards with knowledge execution skills, creativity, and social character required by the future society. Future talent awards should have core competencies such as knowledge, execution, and character. We intend to focus on the core competencies of Christian talent, which embodies life as a conventional believer in which Christian knowledge and life are integrated, to provide answers based on the word of God to ethical and moral questions of future society[18].

Emphasizing faith as a key element of Christianity and Christian talent capacity, it is a gift given by the Holy Spirit based on the great death of Jesus Christ, a manipulative definition to know and trust God through the restoration of his relationship with God, and live a God-centered life with his will in the community of faith. Furthermore, it was argued that faith is the most important and fundamental foundation of the Christian life, so religious elements must have an opinion about Christian talent and core competencies and that major scholars explored the definition of faith and produced the components of faith. In other words, the components of faith are clear and correct cognition of God, clear and specific knowledge of God, feelings of trust in God, and acts of will by God's word. As such Christian talent should be able to realize the core competencies required by future societies together based on the biblical worldview, based on the willful practice of thinking, believing, and knowing specific actions[19].

\section{Conclusion}

We live in the 21 st century with a rapidly changing knowledge and information society. These societies are disrupting the identity of the Christian faith due to various information coming like a flood. This confusion cannot be avoided by anyone, and efforts to search for a new order are needed to avoid it. Christian education is no exception. Rather, we must find a fundamental solution so as not to fall behind in the era of a new paradigm. The transformation of the new paradigm of 21 st world education 
is theory and practice. This theory and practice are already recorded in the Bible. Philippians 4 says, "Let ye learn, receive, hear, and do what I have seen, and the God of peace will be with you." As mentioned in the Bible, Christian education is the core of Christian education to learn, hear, receive, and do the Word of God. Therefore, the recovery of the community of Christian families will be restored through the process of knowing God to do. Therefore, to find out the direction of Christian home education in the 21 st century, we would like to examine the relationship between the church and home, the role of home, and the direction of Christian education.

The Christian talents argue that every basis of attitude and behavior should be placed on knowledge of God, that in every realm of life, it should be able to reveal the sentiments of trust toward God, and that it should be able to respond to all the actions and events that occur in life based on the sentiments of trust toward God. Based on the knowledge of God and the sentiment of trust toward God, we should be able to lead the future society based on the ability to efficiently utilize technology, knowledge, and information, and the ability to creatively utilize it, as well as the ability to self-manage and develop life.

With the advent of the Fourth Industrial Revolution, we urgently demand changes and improvements in the overall education system, and in this regard, Christian education cannot be an exception. The OECD (2003)[20], which presented six scenarios and four models of future schools, presented the following directions and characteristics of changes in school education in the 21 st century: first, school education should be the foundation for lifelong learning; second, schools should be able to educate the core competencies required by future societies; third, personalized learning should be possible, and; fourth, we should establish a learning ecosystem that can find and nurture students' interests and aptitudes. Therefore, measures to foster Christian future talent with the capacity to lead the era of the Fourth Industrial Revolution should be made in a way that fully reflects these factors.

\section{References}

[1] Dong-Il Kim, A Study on the Social Activity and Lifelong Education of the Korean Church -Focusing on the Church in Honam Area-, Asia-pacific Journal of Multimedia Services Convergent with Art, Humanities, and Sociology, (2019), Vol.9, No.11, pp.67-79, DOI: 10.35873/ajmahs.2019.9.11.007

[2] Seung Heon Yang, Christian teaching, Book publishing Dimode, (2012)

[3] H. Fletcher, Education in education, Religion education in ancient Israel: From outbreak to AD 70, Book publishing wish, (2012)

[4] Dong-Il Kim, Proposal of a dedicated civil service system for vitalizing lifelong education, Asia-pacific Journal of Multimedia Services Convergent with Art, Humanities, and Sociology, (2019), Vol.9, No.12, pp.27-36, DOI: 10.35873/ajmahs.2019.9.12.003

[5] Byung Hwan Kim, Calvin's study in terms of social services, Mokyang, (2010)

[6] Ki Duk Hwang, A Study on the Renewal of Diaspora Korean Church by Missionary Church Theory, Graduate School of Pastoral Studies at the Presbyterian Theological University, Doctoral Dissertation, (2017)

[7] Mi Na Lee, Dong-Il Kim, Young-Mi Cho, Ok Hee Na, Kyung Sook Kim, Mi Kyung Kim, life-cycle parenting, Kyoyookbook, (2020)

[8] Sung Chul Hong, Family Influences on John Wesley, Theology and Missionary, (1992), Vol.17.

[9] Ran Hye Kang, The role of father and child development from the biblical point of view, Grishim, (2012)

[10] Joon Kwan Eun, Educational theology: The heretical basis for Christian education, Christian Calligraphy Society, (1976)

[11] Hee Young Jeong, Gap Soon Jeong, Dong Chun Kim, Mi Kyung Kim, Eun Joo Kang, Young Hae Choi, The theory 
and practice of Christian parent education, Changsha, (2007)

[12] Jin Ha Kim, In the era of the Fourth Industrial Revolution, we seek strategic countermeasures against future changes in society, KISTPEP INI, (2016), No.15, pp.45-58.

[13] Eun Chul Lee, Sun Woo Nam, Sung Ah Lee, Developing an interest level scale of the church education program for measuring the effectiveness of church education activities, Journal of Christian Education in Korea, (2018), No.54, pp.243-275, DOI: 10.17968/jcek.2018..54.007

[14] Hwa Seon Jang, Competence-Based Education in light of Christian Education, Journal of Christian Education in Korea, (2015), No.43, pp.109-136, DOI: 10.17968/jcek.2015..43.005

[15] Geung Min Nam, A Study on Christian Education in the 4th Industrial Revolution Era-Focused on Education PlatformGraduate School of Presbyterian University Theological Seminary, Master Thesis, (2018)

[16] Young Hee Lee, Ji Hyun Yoon, Seop Geun Hong, Jae Pil Lim, Byung Bu Baek, A Meta-Analysis of the New Challenges and Approaches for Future Education, Journal of Education \& Culture, (2018), Vol.24, No.5, pp.127-153, DOI: $10.24159 /$ joec. 2018.24 .5 .127

[17] Sang Deok Choi, Sang Eun Lee, Jang Wan Ko, Ki Heon Kim, Kyung Sook Kim, Kyung Eun Kim, Establishment of core competency education and innovative learning ecosystem for fostering future talent, Korea Educational Development Institute, (2013)

[18] Eun Ha Cho, A Critical and Creative Study on Christian Youth Education, Journal of Christian Education in Korea, (2013), No.34. pp,147-168, DOI: 10.17968/jcek.2013..34.006

[19] Jung Gi Lee, An analysis and development plan of competency evaluation index for religious teachers training institutes: focused on the department of Christian education, Journal of Christian Education in Korea, (2019), No.60, pp.45-72, DOI: 10.17968 jcek.2019..60.002

[20] OECD Education 2030 Project based on the 21st Century Capacity Framework, The Education Ministry, (2003) 